\title{
Boundaries and identities in religious conversion: The mirror
}

\author{
Massimo Leone \\ University of Siena, \\ Via dei Pittori 41, 53000 Siena, Italy \\ e-mail: leone2@unisi.it
}

\begin{abstract}
Religious conversion revolutions the boundaries which delimit personal identity. Therefore, the main semiotic problem of mental and cultural representations of this religious phenomenon is to convey simultaneously a feeling of sameness and otherness, identity and change. In the present paper, mirrors are analysed as cultural mechanisms which enable representations to accomplish this paradoxical task. After a brief survey concerning literature on mirrors, some early-modern religious texts using these optical instruments as representative devices are analysed in-depth: a painting of the Magdalene's conversion by Artemisia Gentileschi, an engraving representing conversion from a 17th-century French book, a fragment from Sainte Theresa's spiritual autobiography, a passage from John Calvin's Institution de la religion chrétienne. In its conclusion, the paper underlines the importance of Saint Paul's metaphoric conception of mirrors for the cultural history of these objects, and tries to define the role which cultural semiotics should play concerning this kind of representative mechanisms.
\end{abstract}

In this paper of mine, I shall point out the way in which a particular object, the mirror, functions as a cultural mechanism, which allows a complicated dialectics between identities and their boundaries.

Personal and collective identities are guaranteed by the presence of some limits, borders, thresholds, boundaries, and so on. These terms are not synonyms, but can all be interpreted as words, which contribute to designate the semiotic shape of an object, especially in the case of human beings or groups of people.

This semiotic shape can be affected by different kinds of changes, which can be called troubles, improvements, decays, and so on, depending on which axiological evaluation is attributed to the change 
itself. "Change" and "modification" are rather neutral terms, which do not imply any encomiastic or derogative judgement.

Certainly, religious conversion is an extremely important change in the life of a person. As an extensive literature on this topic has pointed out - literature to which it is not possible to refer on the present occasion - there are various types of religious changes, and different kinds of religious conversion (James 1902; Rambo 1982, 1993; Oksanen 1994). However, all these kinds give rise to problems of identity.

From a cognitive point of view, religious conversion is a paradigmatic form of change, since individuals cannot decide to which beliefs in general, and to which religious beliefs in particular, they want to believe. Conversion, as it has been represented in Christian culture, is quite independent from individual will.

As a consequence of this impossibility to totally control beliefs, religious conversion is very problematic for the feeling of personal identity. When one converts to another religion, one inevitably experiences a paradoxical status: the awareness of the change is fundamental for the identity of the converted person, yet at the same time this awareness is a severe obstacle for the perception of the wholeness of the self. Difference and similarity, otherness and identity paradoxically coexist in the representations of religious conversion.

This happens not only in the case of mental representations, but also in the case of cultural representations of conversion.

In particular, pictorial texts representing conversion seem to face the same problem as mental representations. Mutatis mutandis, they both have to use the present in order to represent the past and the future.

On the one hand, conscience works and exists only in the present tense, which a very long philosophical tradition has defined as a moment entrapped between the memory of the past and the expectation of the future (Ricœur 1983). On the other hand, as an abundant semiotic and esthetical literature has meticulously analysed (Calabrese 1985, 1985b), paintings cannot represent time in its extension, but must have recourse to various semiotic stratagems in order to give an effective representation of it. And, although both the nature and effectiveness of these stratagems may vary depending on visual cultures and their histories, this limit of paintings remains unchanged: time must be compressed into a single instant.

Therefore, when these different texts, painted or mental narratives, represent conversion, they must adopt some suitable cultural mecha- 
nisms, which enable them to keep both otherness and identity in the same semiotic space.

As I shall demonstrate in my paper, mirrors, as used by consciences or represented by paintings, are just this kind of cultural mechanism.

Mirroring surfaces are very common in human history, in every time and in every culture, but it is especially after the technical invention of the modern mirror, that they have stimulated human imagination in many different ways. Unceasingly, from the beginning of early-modern history on, poets, writers, visual artists, philosophers, and so on, have represented mirrors and used them as metaphorical devices for their conceptual inventions. Literature on the cultural history of mirrors is particularly copious, but some contributions can be singled out: in 1994, Sabine Melchior-Bonnet published a very interesting essay, still considered one of the most important texts in this field, which borne the title Histoire du miroir (Melchior-Bonnet 1994). Another fundamental essay concerning the same topic is The Mirror and the Man, published by Benjamin Goldberg in 1985 (Goldberg 1985). In Italian, I can recommend the book by Andrea Tagliapietra La metafora dello specchio, "the metaphor of the mirror", particularly concerned with the philosophical implications of this fascinating object (Tagliapietra 1991).

Besides these major contributions, countless articles, from the most disparate points of view, have been written on mirrors, their uses and their representations.

Also, as all semioticians know, mirrors are very important in semiotics, as well as in other twentieth-century humanistic disciplines, such as psychoanalysis or hermeneutics. Umberto Eco's essay on mirrors, first published in 1985 (Eco 1985), was soon translated into many languages and became very popular. But Eco's witty considerations about mirrors, which he afterwards perfected in his most recent semiotic essay, Kant $e$ l'ornitorinco (Eco 1998), concerned more the semiotics of their perception than their cultural relevance. Therefore, it is to another founder of contemporary semiotics, a semiotician more interested in the cultural semiotics of mirrors, that I shall refer in my paper. I am, of course, alluding to Juri Lotman, whose ingenious analyses are the prestigious inheritance of the semiotic school of Tartu.

In 1986, the semiotic school of Tartu organised a fascinating series of seminars about the semiotic relevance of mirrors. In 1997, a selection of articles on the semiotics of mirrors, originally published in the volumes 18, 20, 21, and 22 of the international journal Sign Systems 
Studies (Trudy po znakovym sistemam), were translated into Italian and published with the following title: Il simbolo e lo specchio, "the symbol and the mirror" (Galassi and De Michiel 1997). In this paper of mine, I shall refer in particular to Lotman's brief but dense article "K semiotike zerkala i zerkal'nosti" (1988), which was translated as "La semiotica dello specchio e della specularità".

According to Lotman, since the dichotomy between the space which is internal to a given culture, and the space which is external to it, is a universal element in cultural semiotics, the boundary separating these two spaces is particularly meaningful. This explains why the semiotics of culture is interested in mirrors: mostly, they function as boundaries of semiotic organisations and as frontiers between "our" world and an "alien" world. So, it is argued by Lotman, the simplest mirroring effects, such as the switch between left and right, or internal and external, are signs of different forms of organisation, which are frequently stigmatised as "incorrect" or "disorganised". Therefore mirrors, in the history of culture, are semiotic mechanisms for the description of alien structures.

Lotman's semiotic conceptions about mirrors are a good point of departure in order to analyse the relation between identity, conversion and mirroring effects. According to Lotman, Lewis Carroll first pointed out the semiotic problem of the mirror in his preface to the novel Alice through the looking glass. However, I think that the most accomplished imagination of mirrors as traps for alien cultural structures is to be found in a short text by Jorge Luis Borges, entitled Animales de los espejos, "animals of the mirror", contained in El libro de los seres imaginarios, "The book of imaginary beings", written by Jorge Luis Borges and Margarita Guerrero in 1967 (Borges and Guerrero 1967). This beautiful text refers to a mythical époque, when " $e l$ mundo de los espejos y el mundo de los hombres no estaban, como ahora, incomunicados", "the world of mirrors and the world of men were not separated, as they are now". As the people of the mirror tried to invade the world of men, and were defeated, they were obliged to stay beyond the reflecting surface, and to mirror every human move. This mythical invention is perfectly suitable to function as a literary counterpart of Lotman's semiotic thoughts. Moreover, both the semiotics of Lotman and Borges's short text introduce the topic of mirrors as cultural mechanisms for the representation of conversion very well.

On this occasion, I shall analyse in detail an early-modern pictorial representation of religious conversion, "La conversione della Maddalena", "The conversion of the Magdalene" (Fig. 1), painted between 
1615 and 1616 by the Italian painter Artemisia Gentileschi, one of the very few female painters of Italian modern art history, who was born in Rome in 1593 and died in Florence in 1653. The painting is an oil on canvas, and measures $146,5 \mathrm{~cm}$ by $108 \mathrm{~cm}$. It is signed on the back of the chair "Artemisia Lomi"; Lomi was the real family name of Artemisia Gentileschi's father. The painting is normally exposed in the Galleria Palatina of the Palazzo Pitti, in Florence. It has been exhibited in New York and Rome. At the time of writing, it is part of the splendid exhibition about Artemisia Gentileschi and his father Orazio, host by the Metropolitan Museum of Art, in New York.

As countless historical essays have pointed out, in the ordinances of the Council of Trent, which took place between 1545 and 1563, and was to revolution the whole structure of the Catholic Church, attention was also given to the question of images (Jedin 1935; id. 1975: 235270), which, especially in France, had undergone the attacks of Calvinist iconoclasts. The influence of the Catholic reformation, and the weight of the Catholic Counter-reformation on the art of the end of the sixteenth century and of the first half of the seventeenth century are difficult to overestimate. On this topic too, literature is extensive, and I shall not dwell on it on this occasion. Among the religious themes represented by artists in this historical period, the conversion of the Magdalene is particularly popular. From the beginning of Christian imagery, theological pamphlets, sermons, hagiographies, legends, novels, poems, dramas, engravings, popular visual texts, musical plays, sculptures, paintings and so on have represented the Magdalene and her fascinating life. However, the Magdalene's conversion was particularly represented in the early-modern époque, when the Catholic Church tried to instil a renewed religious fervour in Western Europe. The Magdalene, the sinful woman who had embraced Christian faith after a dissolute life, and was to become one of the dearest followers of Christ, ending her life in eremitic penitence, was a paradigmatic example for a Catholic civilisation shocked by the Lutheran Reform and endangered by heresy and secularisation. Therefore, the Magdalene was a paradoxical character, which expressed very suitably the contradictions of early-modern Catholic Europe. But the representation of this woman, especially her pictorial representation, inevitably implied a problem of ineffability. How was it possible to condense in a single image two opposite identities? What cultural mechanisms were to be adopted, in order to sew the disjointed boundary separating sinfulness and holiness? Let us analyse the way in 
which Artemisia Gentileschi decided to solve this representative problem.

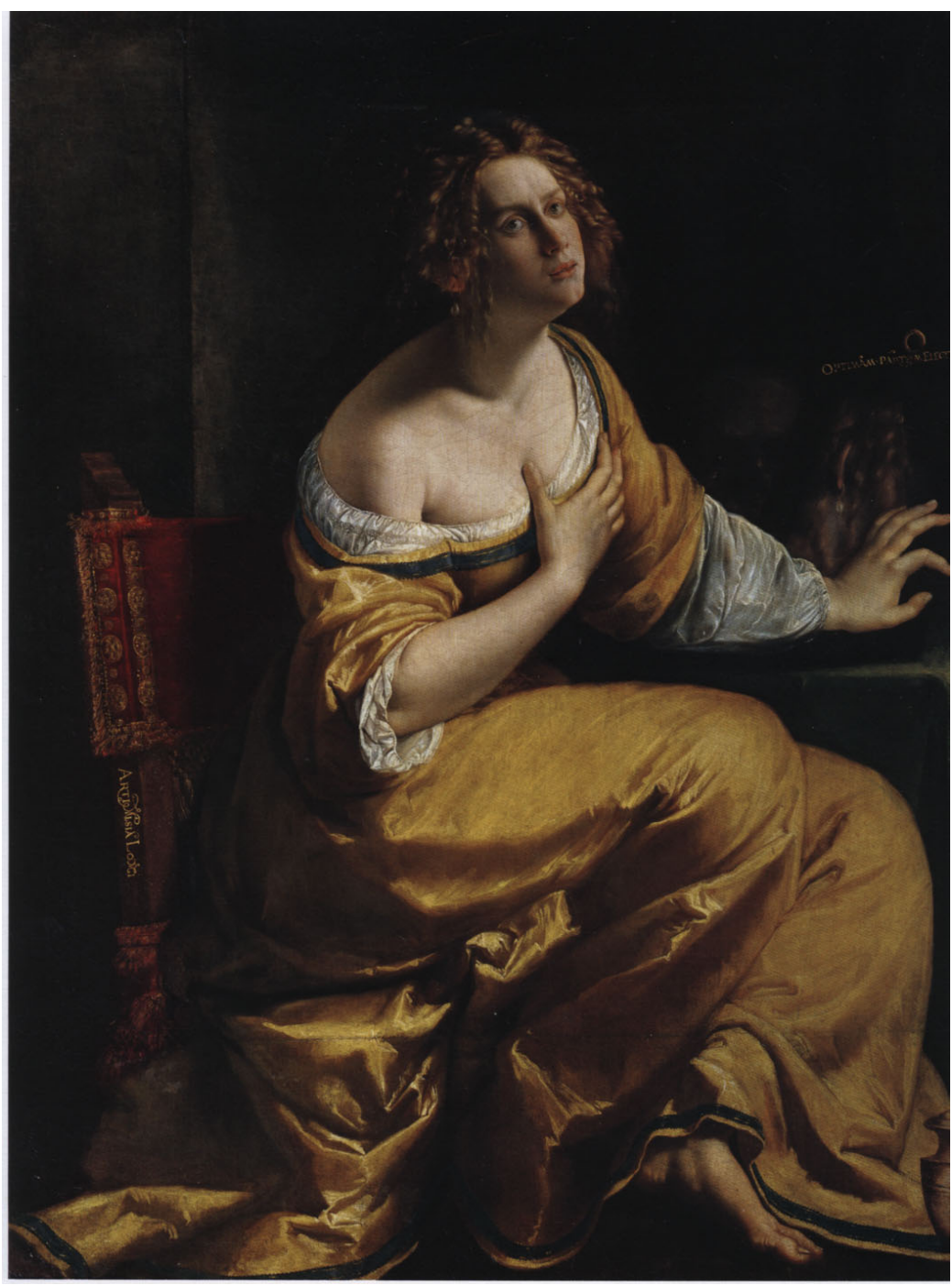

Figure 1. Artemisia Gentileschi, La conversione della Maddalena. 
First of all, I would like to propose a brief verbal description of the painting, in order to point out which elements of it I am going to include in my analysis.

The body of the saint occupies the largest and most central part of the canvas, also being the main source of colour and light. Overall, the posture of the woman follows the traditional iconography of the Magdalene; the disposition of her limbs could be defined as chiastic: on the one hand, the right arm crosses the chest and grasps the left breast, expressing repentance and referring to the saint's carnal and sinful past. On the other hand, the legs of the woman are conspicuously crossed, embodying the same feeling of contrition and perhaps referring to the passion of Christ on the cross. Only the left arm of the woman holds an unusual position, which I shall try to interpret later. The hair and garments of the saint follow the iconographic tradition too: the golden colour of the robe, the elegant green of the edging on both gown and neckline, the sumptuousness of the material, the abundance of wide folds, the ampleness of the neck-opening and the ruffled tawny curls all refer to the Magdalene as courtesan. And, of course, contrition is also embodied in the lineaments of the saint's face. In my analysis, I shall not dwell on these transparent elements, but I shall give attention to four peculiar details:

(1) the inscriptions;

(2) the mirror;

(3) the skull;

(4) the pendant-earrings.

Two inscriptions appear in the painting, the first one from the left on the back of the chair, the second one on the frame of the mirror. Some art historians have claimed that probably these inscriptions are not original, and have been added to the painting (Spike 1991; Bissell 1999: 209-211). A tragic event in Artemisia Gentileschi's life is related to these inscriptions. The 6 May 1611, when Artemisia was not yet eighteen years old, she was raped by Agostino Tassi, painter and assistant of her father. After this event, which was to have huge consequences on Artemisia's both personal and artistic life, Agostino Tassi was brought to trial and banned from Rome. The acts of the trial prove that Artemisia was unable to write. Nevertheless, this does not demonstrate that the two inscriptions in the Conversione are not hers: she could have learned to write after the trial, when she moved to Florence with her new husband. Or, as it has been argued by other art historians, she could have asked someone else to write the two 
inscriptions. However, from a semiotic point of view, this philological question is not very interesting. The meaning of the inscriptions is more relevant. As we have seen, the first inscription is the signature of the painter. The second one is a Latin quotation from the gospel of Luke, 10, 42. It is a reference to an episode, which has been represented obsessively by Western Christian art and concerns the complicated equilibrium between the vita contemplativa, "the contemplative life", and the vita activa, "the active life". I quote this passage from the New Revised Standard Version of the Bible:

Now as they went on their way, [Jesus] entered a certain village, where a woman named Martha welcomed him into her home. She had a sister named Mary, who sat at the Lord's feet and listened to what he was saying. But Martha was distracted by her many tasks; so she came to him and asked, "Lord, do you not care that my sister has left me to do all the work by myself? Tell her then to help me." But the Lord answered her, "Martha, Martha, you are worried and distracted by many things; there is no need of only one thing. Mary has chosen the better part, which will not be taken away from her." (Luke, 10, 42)

The final sentence of this passage translates the Latin inscription in the painting: "optimam partem elegit", "has chosen the best part".

However, the inscription of this sentence in the context of the painting is problematic. First of all, from the Renaissance on, many theologians have denied that the woman represented in the biblical passage be the same as the converted Magdalene. The historical steps through which such a multiple identity has been built are very complicated and cannot be illustrated on this occasion. Nevertheless, the question remains to decide to which "part" the sentence "optimam partem elegit" refers. In the biblical passage, there are two "parts", the contemplative life and the active life. But the choice represented in Artemisia's painting is not between these two parts, but between sinfulness and holiness. The position of the inscription offers a solution to this dilemma. The parts to which the inscription refers are the two cultural structures separated by the mirror, as Lotman would have said. Optimam partem elegit does not mean just that the Magdalene has chosen the contemplative life, but also that she has chosen the right side of the mirror. It is now possible to interpret the position of the Magdalene's left arm, which does not follow the traditional iconography of the saint. The left hand of the Magdalene rejects the mirror as both a symbol of vanity and a separating surface beyond which the wrong part is entrapped, like the mythical enemy in Borges' short 
story. But in order to reject this wrong part and the mirror, which both contains and entraps it, the saint has to touch the reflecting image. So the mirror is not simply a vehicle of a negative identity, but also an optical instrument of perfection, enabling a distinction between good and evil. Therefore, the mirror can function as a cultural mechanism of both conversion and identity, as a paradoxical device, which simultaneously permits change and continuity. Both functions, which frequently appear as fused in the same cultural relation between human beings and mirrors, refer to a very long tradition. But before briefly exploring it, I would like to finish my analysis, by giving attention to the content of the mirror. As Lotman has lucidly stated in his article, what the mirror inverts in its reflection is the wrong side of a cultural structure. In Artemisia's painting, this wrong side is the nape of the neck of the saint, which represents her sinful life, now behind her back, in her past; but it is also the earring-pendant hanging from her left ear. According to a long-established Christian axiology, often the left side represents evil. So, mirrors can function as a device of purification, inverting the left and the right side of an image. Pearls and jewels in general are a traditional symbol of vanity, especially of female vanity, but Artemisia's painting suggests also a more sophisticated dialectics between two different reflecting surfaces: the surface of the mirror and the surface of the pearls. The first one is clear and flat, while the second is opaque and convex. So, in a sort of semisymbolical system (Floch 1995; Calabrese 1999), on the one hand pearls represent the imperfection of the soul (which a long religious tradition describes through the metaphor of the opaque mirror), but also the haughtiness of the soul (as is evident in many early-modern moral emblems, convex mirrors symbolise arrogance because they always magnify what they reflect) ${ }^{1}$ on the other hand, the flat and clean surface of the mirror represents the state of moral awareness of the soul after contrition and repentance. The skull beside the mirror attests that the penitent soul has learned the mortal limits of its vanity.

${ }^{1} \mathrm{Cf}$. the allegorical depiction of vanity painted in the same period by Angelo Caroselli (Rome, 1585-1652). This painting (Fig. 2) represents together a string of pearls, shown in the foreground by the vain woman, a mirror, offered to the young woman by her old servant as an instrument of vanity (right side of the canvas), and a convex reflecting surface (left side). The painting is kept by the Corsini Gallery, in Rome. 


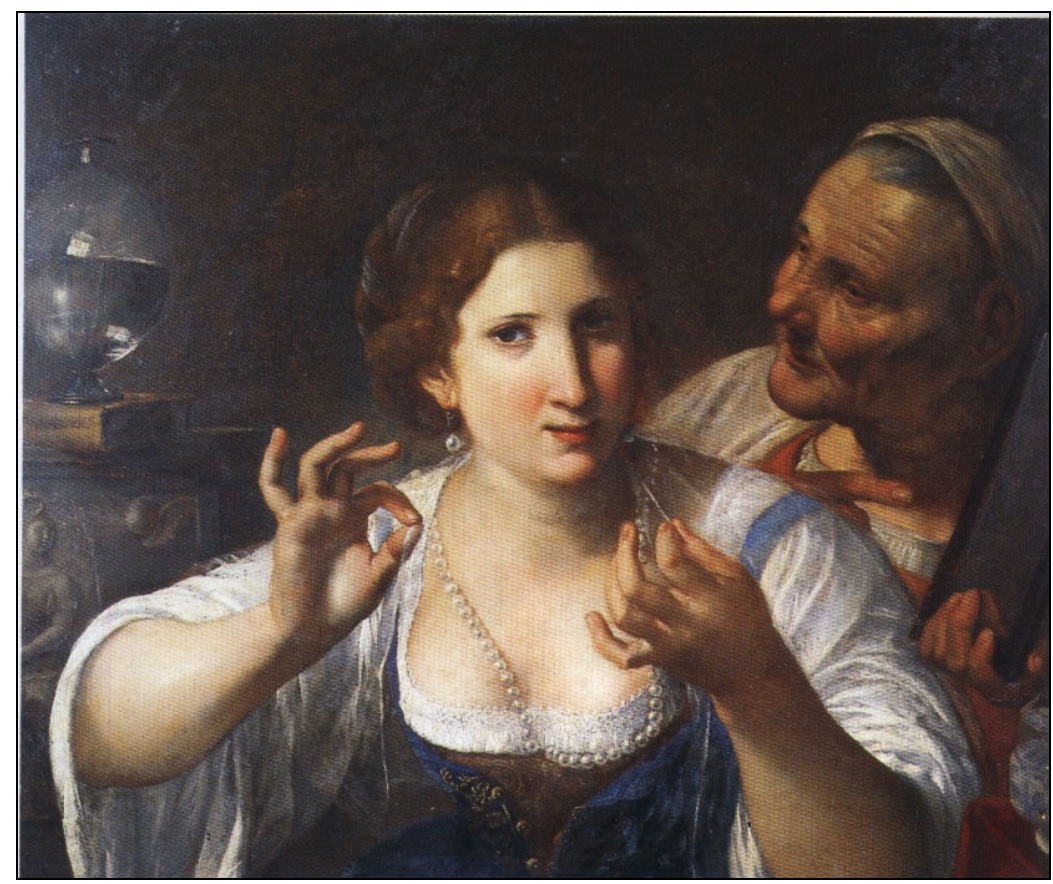

Figure 2. Angelo Caroselli, Vanità.

This painting is not the only example in which conversion and its paradoxical structure is represented through the paradoxical cultural dynamics of a mirror. Artemisia's Conversione della Maddalena was painted between 1615 and 1617. Just a few years later, in 1625, a book was published in Paris, bearing the title Les triomphes de l'amour de Dieu en la conversion d'Hermogène, written by the Capuchin Philippe d'Angoumois (Angoumois 1625). At the page 1170, the book contains a very interesting engraving (Fig. 3), which has been rapidly analysed by the art historian Michel Vovelle, one of the most distinguished experts of popular visual culture (Vovelle 1982).

The engraving represents a young man kneeling before an altar, who contemplates the image contained in a mirror held by an angel. The friar, who spies on the conversion from behind a column, refers to a very long iconographic tradition, according to which miracles and other marvellous events always need the presence of a hidden witness, who will be able to recount and describe what he has seen. The gar- 
ments of the young man are very sumptuous, and are a customary reference to a sinful life, full of elegance and vanity. Also the posture of the convert is quite traditional, and refers plastically to both the crucifix on top of the altar and to the cross, interwoven in the altarcloths.

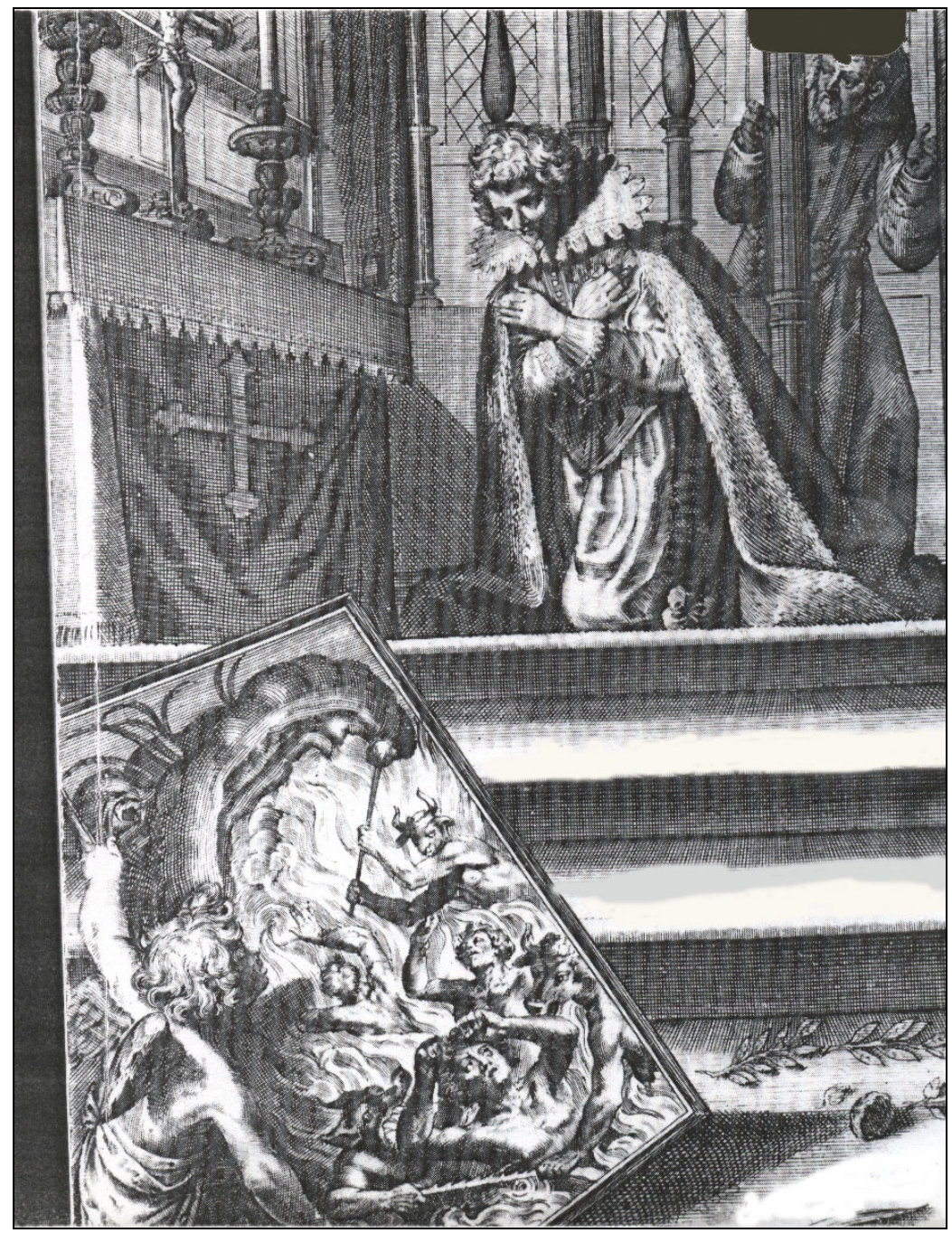

Figure 3. An engraving from La conversion d'Hermogène. 
The most interesting peculiarity of the scene is the mirror. Why should the flat surface held by the angel be called a mirror? Why, if it does not seem to reflect any object of the real world? Several elements can explain this phenomenon. First of all, there is a great resemblance between the converted person and the man tortured by devils in the supernatural image. Second, the angel holds this image as if he were holding a mirror, i.e. trying to enable the young man to see himself in the mirroring surface. Third, the sinner does not look into this surface as if he were observing a painting. From the way in which he bends toward the image, and looks into its depth, he seems to search for himself inside the frame, as one normally does in front of a reflecting image. In other words, in this scene of moralised narcissism, we do not perceive a reflection because there is a mirror, but we perceive a mirror because there is a reflection.

Furthermore, the way in which the sinner is tortured in the guise of his infernal alter-ego is a reference to the semiotic structure of the scene: the sinner is sawn by two monstrous devils, who propose a metaphoric image of a divided self. Again, Lotman's considerations about mirrors as cultural mechanisms are very useful: the mirror separates the young convert from the evil part of his soul.

At the same time, mirrors reflect and invert. As a consequence, they are instruments of both sameness and difference. In the two images, which we have just analysed, the reflected object and the reflected image are both equal and different. But the context of the mirror is a vehicle for a precise moral axiology: the reflected image represents an evil reality, or, as semioticians would like to define it, a "disphoric" structure. Yet now I shall slightly diverge from Lotman's consideration of mirrors, by arguing that in some texts this axiology is inverted. So, a positive connotation is attributed to the reflected image, which is seen as more perfect than the reflected object. The best example of this inversion is to be found in a text written a few years before the appearance of Artemisia Gentileschi's painting, and precisely between 1561 and 1562, when the Council of Trent had almost come to its conclusion. I am talking about the Libro de las Misericordias del Señor, o de las grandezas del Señor, written by saint Therese of Avila. The text was first handwritten by the saint in 1561 in order to satisfy the request of the saint's spiritual director, the Dominican friar Ibañez. Some new chapters were added in 1562. The text is now universally known as Libro de su vida, since it is a spiritual and mystical autobiography of saint Therese. The manuscript of this text, one of the highest achievements of Western Christian 
spirituality, is still kept in the library of the Escorial, in Spain. I quote from the final chapter of the work, chapter forty:

Once, when I was with the whole community reciting the Office, my soul became suddenly recollected, and seemed to me all bright as a mirror, clear behind, sideways, upwards, and downwards; and in the centre of it I saw Christ our Lord, as I usually see Him. It seemed to me that I saw Him distinctly in every part of my soul, and at the same time the mirror was all sculptured - I cannot explain it - in our Lord Himself by a most loving communication which I can never describe. (Teresa of Avila 1962, 341) ${ }^{2}$

This text contains several interesting elements. First of all, in the last sentence the saint expresses three important concepts:

(1) the relation between Jesus and herself is a relation of communication;

(2) this communication is a communication of love;

(3) this communication is ineffable ("yo no sabré decir", "I shall not be able to say").

The mirror is the metaphorical device, which enables the saint to describe this communication. This time, the mirror is not pictorially, but mentally represented. The soul of Therese is like a mirror, which perfectly reflects the face of Jesus. So, the customary axiology of the mirrored image is inverted: the mirror does not entrap an evil structure, but absolute perfection. Yet, the mystical image invented by the saint is more complicated, since Jesus himself becomes a mirror, which reflects the mirror of the Saint's soul. This produces two paradoxical effects:

(1) both Jesus and the saint are simultaneously reflected and transfigured into each other;

(2) this reflection/transfiguration is infinite, like the infinite effect of mirroring produced by opposing two mirrors.

This is not the only text in which Therese of Avila uses the metaphor of the mirror. In the same chapter, she explains that sinful souls are like opaque mirrors, and that heretical souls are like a chipped mirror.

${ }^{2}$ Here follows the original Spanish text: "Estando una vez en las Horas con todas, de presto se recogió mi alma, y parecióme ser como un espejo claro toda, sin haber espaldas ni lados ni alto ni bajo, que no estuviese toda clara, y en el centro de ella se me representó Cristo nuestro Señor, como lo suelo ver. Parecíame en todas las partes de mi alma le via claro, como en un espejo, y tambien este espejo, yo no sé decir cómo, se esculpia todo en el mesmo Señór, por una comunicacion, que yo no sabré decir, muy amorosa" (Theresa of Avila 1987: XL, 124). 
Also, this same metaphor reappears in the final metaphor of the Libro de su vida, where the soul is compared to a mirroring diamond.

It is surprising to realise that the metaphor of the mirror is used in exactly the same way in a Protestant text, the Institutio christianae religionis, written by John Calvin a few years before the Libro de su vida, in Latin in 1535 and in French (Institution de la Religion Chrétienne) in 1541. As Éric Kayayan has pointed out in his essay La portée épistémologique de la métaphore du miroir dans l'Institution de la Religion chrétienne de J. Calvin (Kayayan 1997), the metaphor of the mirror is used thirty-two times in this text, and often in a way which is similar to saint Therese's, for example in the following passage: "Christ is like a mirror, in which it is convenient to contemplate our election, and in which we shall contemplate it without deceit",

So, the tradition of the mirror as a cultural mechanism, which enables complex relations between identities and their boundaries to be expressed, is very long and articulated, and is relevant for two disciplines at least: anthropology and history. On the present occasion, I shall give just a few references about the most important contributions on this topic. From the anthropological point of view, the phenomena, which I have briefly analysed in my paper, have been included in the category of "portalling phenomena", i.e. the cross-culturally common mystical experiences of moving from one reality to another via a tunnel, door, aperture, hole or, of course, through a mirror (MacDonald et al. 1989). Literature on this topic is extensive, but a classic point of departure is the passage which Mircea Eliade wrote on mirrors in his famous book about shamanism (Eliade 1964: 153-155).

From the historical point of view, most Christian texts using the metaphor of the mirror directly or indirectly refer to Paul's famous passage on the mirror in the first letter to the Corinthians $(13,12)$ : «For now we see in a mirror, dimly, but then we will see face to face». The bibliography on the possible interpretations of this sentence, and on the gigantic tradition generated by it, is impressive. One of the best contributions on this topic, on which unfortunately it is impossible to dwell here, is the book by Norbert Hugedé La métaphore du miroir dans les Epîtres de saint Paul aux Corinthiens (Norbert 1957).

The role that I think cultural semiotics should play concerning mirrors as mechanisms of identity, is to mediate between the different

3 "Christ donc est comme un miroir, auquel il convient contempler notre élection, et auquel nous la contemplerons sans tromperie" (Calvin 1911 [1541]: III.xxiv.5). 
disciplines which study these objects, and to pinpoint what structures and representations are triggered by these fascinating metaphors. In this important activity of interdisciplinary mediation, Lotman and the school of Tartu have made a terrific contribution.

\section{References}

Angoumois, Philippe d' 1625. Les triomphes de l'amour de Dieu en la conversion d'Hermogène, Paris: N. Buon.

Bissell, R. Ward 1999. Artemisia Gentileschi and the Authority of Art. University Park: Pennsylvania State University.

Borges, Jorge Luis; Guerrero, Margarita 1995. El libro de los seres imaginarios. Buenos Aires: Emecé.

Calabrese, Omar 1985a. La macchina della pittura: pratiche teoriche della rappresentazione figurativa fra Rinascimento e Barocco. Roma: Laterza.

- 1985b. Il linguaggio dell'arte. Milano: Bompiani.

- 1999. Lezioni di semisimbolico: come la semiotica analizza le opere d'arte. Siena: Protagon.

Calvin, John 1911 [1541]. Institution de la religion chrétienne. (Texte de la 1re édition française (1541), réimprimé, sous la direction de Abel Lefranc, par Henri Chatelain, et Jacques Pannier.) Paris: H. Champion.

Eco, Umberto 1985. Sugli specchi e altri saggi. Milano: Bompiani.

- 1998. Kant e l'ornitorinco. Milano: Bompiani.

Eliade, Mircea 1964. Shamanism. Princeton: Princeton University Press.

Floch, Jean-Marie 1995. Identités visuelles. Paris: Presses Universitaires de France.

Galassi, Romeo; Michiel, Margherita De (eds.) 1997. Il simbolo e lo specchio: Scritti della scuola semiotica di Mosca-Tartu. Napoli: Edizioni Scientifiche Italiane.

Goldberg, Benjamin 1985. The Mirror and the Man. Charlottesville: University Press of Virginia.

James, William 1902. The Varieties of Religious Experience; a Study in Human Nature, Being the Gifford Lectures on Natural Religion Delivered at Edinburgh in 1901-1902. New York: Longmans, Green, and Co.

Jedin, Hubert 1935. Entstehung und Tragweite des Trienter Dekretes über die Bilderverherung. Tübinger Theologische Quartalschrift 116: 143-188, 404429.

- 1975. Geschichte des Konzils vom Trent, Band IV/2: Dritte Tagungsperiode und Abschluss Zweiter Halbband - Überwindung der Krise durch Morone, Schliessung und Bestätigung. Freiburg im Br.: Verlag Herder.

Kayayan, Éric 1997. La portée épistémologique de la métaphore du miroir dans l'Institution de la Religion chrétienne de J. Calvin. Revue d'Histoire et de Philosophie Religieuses 77(4): 431-451.

Leone, Massimo. Conversion and Identity, New York: Routledge, forthcoming.

Lotman, Juri 1988. K semiotike zerkala i zerkal'nosti. Trudy po znakovym sistemam (Sign Systems Studies) 22: 3-5. 
MacDonald, George F.; Cove, John L.; Laughing, Charles D., Jr.; McManus, John 1989. Mirrors, portals, and multiple realities. Zygon 24(1): 39-64.

Melchior-Bonnet, Sabine 1994. Histoire du miroir. Paris: Éditions Imago.

Norbert, Hugedé 1957. La métaphore du miroir dans les Epitres de saint Paul aux Corinthiens. Paris: Delachaux et Niestlé.

Oksanen, Antti 1994. Religious Conversions: a Meta-Analytical Study. Lund: Lund University Press.

Rambo, Lewis R. 1982. Bibliography: Current Research on Religious Conversion. Religious Studies Review 8(2): 146-159.

- 1993. Understanding Religious Conversion. New Haven: Yale University Press.

Ricoeur, Paul 1983. Temps et récit. Paris: Éditions du Seuil.

Tagliapietra, Andrea 1991. La metafora dello specchio. Milano: Feltrinelli.

Spike, John 1991. Review of the catalogue Artemisia (Casa Buonarroti, 18 giugno - 4 novembre), ed. by Roberto Contini and Gianni Papi, Roma. Burlington Magazine 133: 732-734.

Teresa of Avila, saint 1962. The Life of St Teresa of Avila. Including the Relations of her Spiritual State. Written by Herself. London: Burns \& Oates.

- 1987. Libro de su vida. In: Obras de Santa Teresa. Madrid: Aguilar.

Vovelle, Michel 1982. La conversion par l'image: des vanités aux fins dernières en passant par le macabre dans l'iconographie du XVIIe siècle. In: Godard de Donville, Louise (ed.), La conversion au XVIIe siècle: Actes du Colloque de Marseille (janvier 1982). Marseille: Centre Méridional de Rencontres sur le XVIIe siècle.

\section{Границы и идентичности в религиозном обращении: зеркало}

Религиозное обрашение производит коренную ломку границ, которыми очерчена личностная идентичность. Поэтому основной семиотической проблемой ментальной и культурной репрезентации этого религиозного феномена является одновременная передача ощущения тождества и различия, идентичности и изменения. В данной статье зеркала анализируются как культурные механизмы, которые предоставляют возможность изображениям разрешить эту парадоксальную задачу. Предпринимается более глубокий анализ нескольких религиозных текстов раннего Нового времени: картина Артемизии Джентилески, изображающая обращение Марии Магдалины; гравюра из французской книги 17-го века, представляющая обращение; фрагмент из духовной автобиографии Святой Терезы; отрывок из Institution de la religion cretiénne ("Наставление в христианской вере") Жана Кальвина. В заключении подчеркивается важность метафорической концепции зеркала Св. Павла для культурной истории этих объектов и предпринимается попытка определить роль, которую может играть семиотика культуры в связи с этим типом репрезентативных механизмов. 


\section{Piirid ja identiteedid religioosse pöördumise puhul: peegel}

Religioosne pöördumine revolutsioneerib piirid, mis määravad isiksuse identiteedi. Seetõttu on selle religioosse fenomeni mentaalsel ja kultuurilisel representatsioonil põhiliseks semiootiliseks probleemiks samasuse ja erinevuse, identsuse ja muutuse üheaegne edasiandmine. Artiklis analüüsitakse peegleid kui kultuurimehhanisme, mis võimaldavad kujutistel lahendada seda paradoksaalset ülesannet. Põhjalikumalt vaadeldakse järgmisi varase Uusaja religioosseid tekste: Artemisia Gentileschi maal, millel on kujutatud Maria Magdalena pöördumine; gravüür XVII sajandi prantsuse raamatust; fragment Püha Theresa autobiograafiast; katkend John Calvini tekstist Institution de la religion chrétienne. Rõhutatakse Püha Pauluse peegli metafoorilise kontseptsiooni tähtsust nende objektide kultuurilise ajaloo jaoks ja püütakse määratleda kultuurisemiootika roll seda tüüpi representatsioonimehhanismidega seoses. 